Ewa Jaska

Agnieszka Werenowska

Szkoła Gtówna Gospodarstwa Wiejskiego w Warszawie

Bartosz Gomola

\title{
Wykorzystanie influencer marketingu w kreowaniu wizerunku marki
}

\section{THE USE OF INFLUENCER MARKETING IN CREATING THE BRAND IMAGE}

\begin{abstract}
Celem artykułu jest zdefiniowanie influencer marketingu $i$ jego wykorzystania $w$ procesie kreowania wizerunku marki oraz podejmowania decyzji zakupowych. Scharakteryzowano pojeccie influencera, zastosowanie Facebooka i Instagramu w tym zakresie. Wykorzystujac przykłady 4 marek ( Żywiec Zdrój, Huawei, Daniel Wellington, NA-KD) opisano udziat ambasadorów i influencerów $w$ procesie kreowania wizerunku marek oraz promocji ich produktów. Przeprowadzono badanie ankietowe aby zweryfikować zalożenie badawcze dotyczace wpływu influencerów na rozpoznawalność $i$ wizerunek marki oraz podejmowanie decyzji zakupowych. Marki Daniel Wellington oraz NA-KD wykorzystano do zilustrowania potencjatu istniejacego w twórcach posiadajacych mate zasięgi na platformach społecznościowych, a marki Żywiec Zdrój $i$ Huawei wspótpracowaty z rozpoznawalnymi influencerami będacymi równocześnie ich ambasadorami (M. Wojciechowska i K. Wojewódzki). Jak wynika z przeprowadzonego badania ambasadorowie marek a zarazem influencerzy zwiększaja rozpoznawalność marki $i$ wplywaja najej wizerunek wśród konsumentów. Z kolei polecenie influencera ma większy wpływ na podejmowanie decyzji zakupowych niż ambasadorzy marek. Przeprowadzono analize literatury przedmiotu $i$ materiatów źródlowych, wykorzystano metodę studium przypadku $i$ sondażu diagnostycznego.
\end{abstract}

Słowa kluczowe: influencer marketing, marka, influencer, wizerunek, ambasador marki

\section{Wstęp}

Największe przedsiębiorstwa reprezentujące różne obszary życia społecznogospodarczego posiadają swoje własne kanały w social mediach. Jednak często zasięgi tych profili są niewystarczające, by poinformować wszystkich odbiorców o nowych lub udoskonalonych produktach. Pomocni w tym zakresie są influencerzy oraz ich profile, na których marki w sposób natywny mogą dzielić się swoimi nowymi informacjami. W literaturze przedmiotu najczęściej wymieniane korzyści ze współpracy $\mathrm{z}$ influencerami to zasięg, jakość, storytelling, multichannel i trwałość. Influencerzy budują lojalną publiczność i zapewniają precyzyjne targetowanie. W ocenie przedsiębiorców ich pozytywna rekomendacja jest często skuteczniejsza niż wysokobudżetowa kampania. Z uwagi na to że influencerzy to eksperci $\mathrm{w}$ dziedzinie kontentu i używają nowoczesnych technologii oraz narzędzi, zapewniają tym samym przekaz w wysokiej i satysfakcjonującej markę jakości. Youtuberzy i blogerzy 
to mistrzowie opowiadania historii i tym samym ich przekaz jest bardziej angażujący niż tradycyjne formaty reklamowe. Influencerzy przeważnie korzystają z różnych kanałów komunikacji, jak np. Youtube, Facebook czy Instagram, a także zakładają własne blogi. Istotną korzyścią jest znacznie dłuższa żywotność materiałów influencerów niż wykupiona przestrzeń reklamowa czy czas antenowy. Przedsiębiorstwa korzystają także $\mathrm{z}$ usług podmiotów prawnych oferujących usługi w zakresie influencer marketingu. Na polskim rynku dwie największe agencje to TalentMedia i LifeTube współpracujące $\mathrm{z}$ youtuberami. Pozyskują dla nich zlecenia reklamowe oraz pomagają je realizować, a także produkować i optymalizować treści z punktu widzenia działan marketingowych. W marcu 2019 roku podjęto decyzję o połączeniu tych agencji i w rezultacie powstaje największy podmiot w regionie Europy Środkowo-Wschodniej świadczący usługi influencer marketingu. Jak wynika z szacunkowych danych za 2018 rok, cztery inne agencje influncer marketingu obecne w Polsce zanotowały 33,2 \% przychodów. Tym samym udziały TalentMedia i LifeTube w 2018 roku były na poziomie ok. $70 \%(130 \mathrm{mln}$ subskrypcji i $820 \mathrm{mln}$ wyświetleń) i zrealizowano łącznie 1,2 tys. kampanii dla 430 klientów ${ }^{1}$. Integracja dwóch największych podmiotów na polskim rynku influencerskim stwarza nowe możliwości zarówno klientom, jak i współpracującym twórcom. Agencje zachowują swoje marki, a integracja obejmuje technologie, produkcję treści, public relations i marketing.

Celem artykułu jest zdefiniowanie influencer marketingu i jego wykorzystania w procesie kreowania wizerunku marki oraz podejmowania decyzji zakupowych. W związku z tym przeprowadzono analizę literatury przedmiotu i materiałów źródłowych, wykorzystano metodę studium przypadku i sondażu diagnostycznego, w tym technikę ankiety.

\section{Istota i zakres influencer marketingu}

R. Wilusz definiuje influencer marketing jako „poszukiwanie popularnych i wpływowych osób $\mathrm{w}$ danej dziedzinie i współpracę z nimi nad promocją marki bądź produktu dzięki wykorzystaniu społeczności zorganizowanej wokół tej persony"2. Dlatego tak istotne jest zauważenie przez S. Cooka że „marka nie jest już dziś tym, o czym mówimy konsumentom - jest tym, co konsumenci mówią na jej temat między sobą”. Influencerzy, to „wpływowi liderzy opinii, posiadają wiele atutów, niezwykle atrakcyjnych i dających przewage nad aktualnymi strategiami promocyjnymi”, Natomiast $\mathrm{w}$ słowniku języka polskiego pojęcie influencera jest definiowane jako „osoba, która zdobyła popularność w Internecie i korzysta ze swojej sławy, wpływając na swoich widzów/czytelników, ich światopogląd, gust, etc." . Innymi słowy, jest to osoba, która zgromadziła określoną publiczność na swoich kanałach

\footnotetext{
${ }^{1}$ https://www.wirtualnemedia.pl/artykul/talentmedia-i-lifetube-zintegruja-technologie-i-produkcje-pozostanaosobnymi-markami (20.03.2019)

${ }^{2}$ R. Wilusz: Influencer Marketing potężny ponad miarę, Marketing (r)Evolution. Nowe techniki, pomysły, rozwiązania. Oficyna Wydawnicza Politechniki Rzeszowskiej, Rzeszów 2017, s. 250.

${ }^{3}$ S. Cook: Under the Influence: A New Perspective on Social Marketing. Wyd. skyword.com, London 2015, s. 38.

${ }^{4}$ R. Wilusz, op.cit., s.251.

${ }^{5}$ https://sjp.pwn.pl/ciekawostki/haslo/influencer;6368873.html (18.05.2018)
} 
społecznościowych i dzieli się swoimi opiniami oraz przemyśleniami dotyczącymi konkretnych produktów, mając realny wpływ na decyzję zakupowe swoich obserwatorów.

Influencer marketing stał się popularny dzięki rosnącej popularności mediów społecznościowych. Zaistniała zatem realna potrzeba, aby marki zaczęły korzystać z influencerów. Dzięki wykorzystaniu tego typu promocji, marka jest w stanie zbudować relację na linii produkt - konsument oraz być blisko swoich klientów. Na korzyści wynikające z wykorzystania influencer marketingu wskazuje m.in. R. Wilusz i wymienia takie jak ${ }^{6}$ :

- aktywizacja odbiorców - publiczność zgromadzona w social mediach jest aktywna, responsywna oraz wrażliwa na przekaz;

- $\quad$ widoczny staje się wpływ w obszarze podejmowanych działań i opinii odbiorców;

- autentyczność - influencer postrzegany jest jako głos konsumenta co pozwala marce przypisać ludzki wymiar, który jest doceniany przez odbiorców;

- zaufanie - cechy osobowościowe influencerów mogą wzbudzić w odbiorcy sympatie. Konsumenci zaczynają bardziej ufać takiej osobie niż tradycyjnemu przekazowi;

- $\quad$ relacje - influencer może być w ciagłym kontakcie ze swoimi obserwatorami.

Znaczenie cech osobowościowych influencerów w budowaniu relacji marka konsument zauważa także K. Stopczyńska i twierdzi że taka osoba powinna być ${ }^{7}$ :

- angażująca - tylko wtedy będzie kreowana potrzeba częstych kontaktów na różnych platformach komunikacyjnych;

- $\quad$ aktywna - budowanie stałego kontaktu i niemal przyjacielskich relacji;

- autentyczna - tylko wtedy podejmowane działania nie będą odbierane jako nachalne i perswazyjne;

- $\quad$ ekspertem - tylko posiadanie pełnej wiedzy pomaga w kreowaniu oczekiwanych relacji i skutecznym oddziaływaniu;

- selektywna - rozpatrywać propozycję współpracy z innymi firmami w perspektywie dotychczasowych relacji $\mathrm{z}$ odbiorcami i czy pozwoli to na budowanie nie tylko własnej marki, ale przede wszystkim firmy.

\section{Facebook i Instagram - najczęściej wykorzystywane media społecznościowe w działaniach marketingowych przedsiębiorstw}

Podstawową funkcją social media $\mathrm{w}$ marketingu jest prowadzenie badań, analiz oraz pozyskiwanie informacji dotyczących potrzeb grupy docelowej. Jest to również ważne źródło pozyskiwania opinii i postaw konsumentów na temat marki. Dodatkowo aktywne prowadzenie profili $\mathrm{w}$ social mediach skutkuje dwukierunkową komunikacją z klientami, lub potencjalnymi nabywcami. D. Kaznowski wyróżnia media służące dyskusji i komunikacji, bieżącemu komentowaniu i informowaniu, wymianie poglądów,

\footnotetext{
${ }^{6}$ R. Wilusz, op.cit., s.251-252.

${ }^{7}$ K. Stopczyńska: Wykorzystanie influencer marketingu w kreowaniu relacji z klientami pokolenia Y. Studia Oeconomica Posnaniensia, 2018,vol.6, nr 5, s.108-109.
} 
współtworzeniu i współdzieleniu zasobów, a także budowaniu i podtrzymywaniu relacji, co jest szczególnie istotne w kreowaniu wizerunku marki ${ }^{8}$.

Tego typu funkcje są charakterystyczne dla Facebooka, który jest jednym z najczęściej wykorzystywanych mediów w działaniach marketingowych przedsiębiorstw. Jedną z najważniejszych funkcji Facebooka jest możliwość stworzenia spersonalizowanej strony marki, na której można publikować treści i gromadzić coraz większe grona potencjalnych interesariuszy. $\mathrm{Za}$ pośrednictwem profilu marki na Facebooku można dzielić się różnymi informacjami, jak np. godziny otwarcia sklepów stacjonarnych, prezentować ofertę produktowa, zapowiadać nowe produkty, publikować gazetki promocyjne a także informować o promocjach ${ }^{9}$.

Profil marki na Facebooku wywołuje wśród obserwatorów poczucie uczestnictwa w życiu marki. Dodatkowo obserwatorzy identyfikują się z marką, poprzez wgląd w zakulisowe sceny publikowane na profilu w postaci np. relacji zdjęciowej $\mathrm{z}$ konkretnego wydarzenia lub kulisów powstawania spotu reklamowego.

Każdy użytkownik Facebooka może polubić stronę marki. Zaobserwowanie tego typu stron wynika głównie z zainteresowania marką przez użytkowników i potrzeby pozyskiwania informacji na bieżąco o nowych produktach lub oferowanych usługach. Z perspektywy marki jest to istotny element, gdyż poprzez polubienia buduje się społeczność. Dodatkowo polubienie strony powoduje, iż w momencie publikacji nowego postu na profilu pojawi się on na tablicy osoby, która polubiła daną stronę. Można więc traktować tego typu posty jako darmową reklamę, pod warunkiem, że zawartość takiego postu będzie interesująca z perspektywy użytkownika. W przeciwnym wypadku istnieje szansa, że dotychczasowi subskrybenci przestaną obserwować profil marki.

Polubienie strony marki jest bardzo istotne, natomiast stanowi jedynie część sukcesu. Dzięki udostępnieniom, posty docierają do znajomych osób udostępniających $\mathrm{i}$ tym samym budowany jest większy zasięg. Dodatkowo w sytuacji, gdy dany użytkownik udostępni post marki, staję się influencerem, który poleca treści w nim zamieszczone i powstaje potencjalna szansa na powiększenie społeczności biorącej udział w życiu marki ${ }^{10}$.

Osoby odpowiedzialne za prowadzenie konkretnej marki na Facebooku powinny pamiętać, że najważniejsze nie jest posiadanie jak największej liczby obserwatorów, ale wykreowanie relacji marka-konsument ${ }^{11}$. Facebook umożliwia również łatwiejszy sposób dotarcia do grupy docelowej marki, stwarzając sposobność do opublikowania postu sponsorowanego. Pamiętać jednak trzeba, że tego typu reklama niesie za sobą ryzyko, bowiem należy do reklam droższych i aby dany użytkownik zainteresował się informacją zawartą w poście sponsorowanym musi go otworzyć. Stąd celem marki w tego typu działaniach powinno być zachęcenie użytkowników, aby nie tylko odwiedzili ich profil na Facebooku, ale również polubili.

\footnotetext{
${ }^{8}$ D. Kaznowski: Social media - społeczny wymiar Internetu. [w:] E-marketing. Współczesne trendy, Red. naukowa J. Królewski. P.Sala, Wyd. PWN, Warszawa 2013, s.71.

${ }^{9} \mathrm{~K}$. Wicińska: Media społecznościowe jako narzędzie rozwijające działania marketingowe przedsiębiorstw, Czasopismo Rynek - Społeczeństwo - Kultura, Nr 3(24) 2017, s. 117.

${ }^{10}$ B. Stopczyński: Facebook w komunikacji marketingowej - użyteczność dla firm rodzinnych, Przedsiębiorczość i Zarządzanie, T.XV, Zeszyt 7, Część III/ 2014 s. 142-144.

${ }^{11}$ D. Kaczorowska-Spychalska: Blogi w procesie komunikacji marketingowej, Wyd. Uniwersytetu Łódzkiego, Łódź 2016, s. 11.
} 
Kolejną ważną funkcją Facebooka, jest uzyskiwanie szybkiej informacji zwrotnej od konsumenta dotyczącej produktów lub usług. Ciagły i codzienny kontakt z użytkownikami pomaga zwrócić uwagę na zmiany postaw i zachowań oraz na czynniki, które te zmiany wywołują. Dodatkowo przedsiębiorstwo ma możliwość indywidualnego traktowania każdego konsumenta i budowania lojalnych relacji z konsumentem ${ }^{12}$. Prowadzenie fun page'a dostarcza również marce informacji, które są wykorzystywane w poprawianiu skuteczności prowadzonego profilu, takich jak np. popularne godziny publikacji czy miasta, z których użytkownicy są najbardziej aktywni.

$\mathrm{Za}$ skuteczne i efektywne medium wykorzystywane $\mathrm{w}$ influencer marketingu uznawany jest także Instagram. Niemal każdego dnia pojawia się na nim około $95 \mathrm{mln}$ zdjęć i filmów, a użytkownicy pozostawiają blisko 4,2 mld lajków pod treściami. Jak wynika z badania Influencer Marketing Hub 2017 Study wartość influencer marketingu na Instagramie w 2018 roku oszacowano na 1,7 mld dolarów, czyli o 0,5 mld więcej niż w 2017 roku, chociaż dynamika wzrostowa była znacznie większa w latach 2016/2017 ${ }^{13}$.

Instagram posiada zarówno aplikację mobilną, na której można przeglądać i dodawać posty oraz stronę internetową, która umożliwia wyłącznie przeglądanie zdjęć czy filmów. Tworząc swój profil, użytkownik publikuje na nim materiały, a dodatkowo buduje sieć profili, którą obserwuje. Każda osoba posiadająca profil buduje również swoją sieć followersów - obserwatorów. Im więcej obserwatorów posiada dany profil, tym jego post dociera do większej liczby osób, osiągając większy zasięg.

Portal oferuje swoim użytkownikom szereg filtrów, które można nałożyć na zdjęcia i filmy, aby nadać im odpowiedni charakter. Publikując materiał, użytkownik ma również możliwość opisania go odpowiednim hashtagiem, który jest powiązany z materiałem, np. publikując zdjęcie z podróży, można opisać go hashtagiem \#travel. Hashtagi to inaczej znaczniki, które ułatwiają innym użytkownikom wyszukanie zdjęcia $\mathrm{z}$ danej kategorii. Posty umieszczone na Instagramie można udostępniać na inne portale społecznościowe, takie jak: Facebook, Twitter, Tumblr i Flickr. W połowie 2016 roku Instagram umożliwił również publikowanie InstaStories w postaci zdjęć oraz krótkich filmów, które widoczne są wyłącznie przez 24 godziny od momentu publikacji.

$\mathrm{Na}$ Instagramie pojawia się coraz więcej reklam. To co odróżnia je od innych reklam, np. na Facebooku to brak nachalności. Posty sponsorowane przypominaja standardowe posty, które publikują użytkownicy. Zauważalna jest tendencja do większego wykorzystania Instagramu w działaniach reklamowych ${ }^{14}$. Marki, tworzą swoje oficjalne profile, na których dodają materiały związane $\mathrm{z}$ produktami i świadczonymi usługami.

Duża część użytkowników obserwuje oficjalne profile marek w celu uzyskania kodów zniżkowych lub innego rodzaju promocji. Coraz częściej organizowane są różnego rodzaju konkursy, w których do wygrania są produkty oferowane przez markę organizującą dane wydarzenie. Podejmowanie tego typu aktywności wpływa wzrost poziomu sprzedaży, ale również na budowanie lojalnej grupy odbiorców. Użytkownicy czekający na promocję obserwują profile marek.

\footnotetext{
${ }^{12}$ D. Kirkpatrick: Efekt Facebooka, Wyd. Wolters Kluwer, Warszawa 2011, s.217-237.

${ }^{13}$ The rise of influencer marketing. https://influencermarketinghub.com/the-rise-of-influencer-marketing (2.03.2019)

${ }^{14}$ https://nowymarketing.pl/a/8830,8-nietypowych-taktyk-na-wypromowanie-tresci-w-social-media (12.04.2018)
} 
Często zdarza się, iż konsumenci, na swoich prywatnych profilach, publikują posty, na których widoczne są produkty konkretnej marki. Wraz z opublikowaniem tego rodzaju postów użytkownicy oczekują interakcji ze strony profilu marki. Komentując lub publikując taki post na profilu marki, konsument ma poczucie zainteresowania i uznania. Coraz cześsiej Instagram wykorzystywany jest do prowadzenia kampanii, wykorzystując profile użytkowników, których zadaniem jest publikacja zdjęć z produktami konkretnych marek.

Przykładem kampanii opartej na obecności influencerów w działaniach promocyjnych jest kampania Polskiej Organizacji Turystycznej pt. \#VISITPOLAND realizowana od czerwca 2018 do czerwca 2019 z udziałem 7 twórców popularnych kanałów YouTube ${ }^{15}$. Dla każdego twórcy powstał osobny scenariusz wizyty, obejmujący miejsca i wydarzenia odpowiednie do indywidualnych zainteresowań oraz stylu tworzonych filmów. W 2018 roku wizytowano Podlasie, Pomorze, Dolny Śląs, Małopolskę i Podkarpacie. Do końca września 2018 roku zrealizowano 5 z 7 podróży studyjnych i opublikowano 8 filmów na YouTube, które wyświetlono 961898 razy. Zamieszczono także 23 zdjęcia na Instagramie, które polubiły 895324 osoby i 65 Instastories o średniej oglądalności 40 tys. odsłon (łącznie 2,6 mln), czyli całkowite zaangażowanie to ponad 4,4 mln. Zasięg kampanii w mediach społecznościowych był planowany na poziomie $11 \mathrm{mln}$, czyli w pierwszych trzech miesiącach plan zrealizowano w $40 \%$.

\section{Uczestnictwo influencerów w kreowaniu wizerunku przedsiębiorstwa w opinii badanych}

$\mathrm{W}$ ramach przeprowadzonego badania ankietowego wykorzystano marki takie jak Żywiec Zdrój, Hauwei, Daniel Wellington i NA-KD. Dwie pierwsze to przykłady postrzegania marki przez konsumentów w sytuacji kryzysowej, a pozostałe były wybrane do zilustrowania potencjału twórców posiadających małe zasięgi na platformach społecznościowych.

W badaniu uczestniczyły 104 osoby. Zdecydowaną większość, czyli ponad $71 \%$ stanowiły kobiety. Około 96\% respondentów to były osoby w wieku 19-30 lat. Najliczniejszą grupę (46\%) stanowili studenci pracujący. Były to osoby legitymujące się wykształceniem wyższym $(57 \%)$ i średnim $(43 \%)$. Osoby biorące udział w badaniu ankietowym to głównie reprezentanci miast powyżej 500 tys. mieszkańców (47\%), terenów wiejskich (16\%) i miast do 30 tys. mieszkańców (12\%).

\section{Marka „Żywiec Zdrój””}

W 2008 r. producent wody mineralnej Żywiec Zdrój zapoczątkował kampanię „Po Stronie Natury”. Na stronie producenta można przeczytać, że głównym celem akcji jest edukacja Polaków w zakresie dbania o środowisko. W 2018 roku hasłem przewodnim kampanii był plastik i jego recykling ${ }^{16}$.

W kwietniu 2018 roku, Martyna Wojciechowska, podróżniczka oraz prowadząca program „Kobieta na Krańcu Świata”, za pomocą swojego Instagrama poinformowała, że po raz kolejny stała się ambasadorką programu „Po Stronie Natury”. W

\footnotetext{
${ }^{15}$ https://zarabiajnaturystyce.pl (10.03.2019)

${ }^{16} \mathrm{https}$ ://www.postronienatury.pl/co-w-tym-roku (13.08.2018)
} 
opublikowanym poście wspomina również o celu głównym kampanii i zachęca do segregowania odpadów M. Wojciechowską na Facebooku obserwuje ponad półtora miliona osób, natomiast na Instagramie zgromadziła ponad 675 tysięcy followersów.

Wszyscy respondenci pozytywnie odpowiedzieli na pytanie kwestionariusza ankiety dotyczące znajomości marki Żywiec Zdrój, a 99\% ankietowanych przynajmniej raz miało kontakt $\mathrm{z}$ tą marką. Niemal $62 \%$ ankietowanych poprawnie wskazało Martynę Wojciechowską jako ambasadora marki. Co trzeci nie potrafił wskazać na żadne nazwisko wymienione w kwestionariuszu ankiety (M. Foremniak, A. Małysz, M. Żebrowski, R. Lewandowski). W dniu 13 czerwca 2018 roku Martyna opublikowała na Facebooku post na temat plastiku i tego, jaki ma wpływ na środowisko. Napisała że plastik ma jedna, główną przewagę nad szkłem, mianowicie jest rozkładalny. W poście przytacza, iż rozkład plastiku trwa od 400 do 1000 lat, natomiast szkło jest nierozkładalne. Dodaje również, iż nie rodzaj surowca, z którego wyprodukowano butelkę jest najważniejszy, lecz postawy społeczne w momencie wypicia zawartości. Pisze również o segregacji śmieci oraz o zaletach korzystania z plastikowych butelek. Post wywołał dużą falę krytyki i 5200 reakcji spośród 7700 było negatywnych. Dodatkowo post zgromadził ponad 2100 komentarzy, średnio o $10 \%$ procent więcej niż pozostałe posty i w większości były to opinie negatywne. Użytkownicy głównie zwracali uwagę na tony śmieci wyrzucanych przez ludzi i ich wpływ na środowisko, na szkodliwe substancje wydzielane $\mathrm{z}$ plastiku pod wpływem ciepła oraz na fakt konsumpcji plastikowych śmieci przez zwierzęta. Z punktu widzenia przedsiębiorstwa niekorzystne były także komentarze dotyczące marki. Internauci zarzucali marce "greenwashing” co w bezpośrednim thumaczeniu oznacza „ekościema”, zielone kłamstwo oraz „zazielanie" faktów. Odnoszono się również do produktów marki i ich składu, zauważając brak troski o konsumentów. Także w ankiecie postawiono pytanie o wpływ wspomnianego postu na postawy respondentów. Prawie $37 \%$ ankietowanych nie słyszało o tym poście, a około $22 \%$ negatywnie oceniło wpływ postu i co piąty badany znający post stwierdził że będzie on miał wpływ na ich decyzje zakupowe w przyszłości i wybór konkurencyjnych marek.

Jak wynika $\mathrm{z}$ powyższej analizy, dobór ambasadorów oraz treść, którą chce przekazać marka są bardzo istotne $\mathrm{z}$ uwagi na skuteczność działań podejmowanych w ramach influencer marketingu, bowiem można wzbudzić negatywne skojarzenia $\mathrm{z}$ marka.

\section{Marka Huawei}

Marka Huawei współpracuje z najbardziej rozpoznawalnymi osobami ze świata sportu i szeroko pojętej kultury. Ambasadorami marki Huawei są między innymi Leo Messi i Robert Lewandowski. W dniu 5 kwietnia 2018 roku firma Huawei poinformowała na premierze swoich nowych, flagowych modeli, że do „\#TeamHuawei” dołączył Kuba Wojewódzki, ,Jeden z najbardziej znanych dziennikarzy w Polsce i influencer obserwowany przez setki tysięcy internautów"17. Kuba Wojewódzki zgromadził na swoich kanałach społecznościowych bardzo dużą liczbę osób. Na oficjalnym profilu na Facebooku w 2018 roku było to 765 tysięcy osób, a na Instagramie ponad 825 tysięcy followersów. Od tej pory, Kuba Wojewódzki zaczął publikować posty $\mathrm{w}$ social mediach, do których dodawał hashtagi \#TeamHuawei

${ }^{17} \mathrm{https} / / /$ consumer.huawei.com/pl/press/news/2018/kuba-wojewodzki-teamhuawei/ (13.08.2018) 
\#HuaweiP20Pro oraz oznaczał oficjalny profil marki @huaweimobilepl. Do niektórych zdjęć dokładał również nakładkę, która wyraźnie wskazuje, że zdjęcie zostało stworzone przez smartfon marki Huawei. Jak wynika z badania 100\% respondentów odpowiedziało pozytywnie na pytanie dotyczące znajomości marki Huawei. Dodatkowo prawie 45\% respondentów chociaż raz korzystało z produktów tej marki. Była to marka najlepiej rozpoznawana spośród pozostałych wykorzystanych w badaniu. Respondentów zapytano również o ambasadora marki Huawei. Ankietowani mieli do wyboru: K. Wojewódzkiego, M. Rozenek, J. Błaszczykowskiego, K. Ibisza i T. Kota. 67\% ankietowanych stwierdziło, iż żadna osoba z powyższych nie jest ambasadorem marki Huawei, a jedynie co piaty badany odpowiedział prawidłowo.

Niedługo po oficjalnym wstapieniu do teamu Huawei, tj. 17 kwietnia 2018r., Kuba Wojewódzki opublikował zdjęcie, na którym ogląda telewizję siedząc w mieszkaniu. Na pierwszy rzut oka zdjęcie nie wzbudza żadnych dodatkowych emocji. Jednak obserwujący profil dziennikarza followersi zauważyli, że na stole widać opakowanie smartfona iPhona X. Pod zdjęciem pojawiło się wiele komentarzy, w których użytkownicy zarzucali Kubie Wojewódzkiemu zamieszczanie zdjęć z produktami konkurencyjnych marek. Opublikowane zdjęcie wywołało w pierwszej kolejności negatywne komentarze pod adresem dziennikarza, ale także wpłynęło na odbiór marki, bowiem ambasador konkretnej marki jest postrzegany jako osoba korzystająca wyłącznie z jej produktów.

Kuba Wojewódzki odpowiedział w swoim, nieco żartobliwym stylu w komentarzu pod zdjęciem na zarzuty obserwatorów jego profilu. Jednak nie było to wystarczającym aby zmienić odbiór, tym bardziej że największe serwisy internetowe, specjalizujące się w dziedzinie technologii dłuższy czas o tym informowały.

Ankietowani zostali zapytani również o wpływ postu na postrzeganie marki. Dla 45,5\% respondentów znających post był to powód, by w negatywnym świetle zacząć postrzegać markę Huawei. To co jest ważne dla przedsiębiorstwa to niewątpliwie odpowiedź $45 \%$ respondentów, że post ten wpłynął lub wpłynie na ich decyzję zakupową i nie będzie to marka pierwszego wyboru.

\section{Marka Daniel Wellington}

Szwedzka marka Daniel Wellington powstała w 2006 roku. Firma projektuje zegarki w Szwecji, wykorzystuje mechanizmy z Japonii a produkcja odbywa się w Chinach. Firma początkowo była startupem, w który zainwestowano 15 tys. $\${ }^{18}$. $\mathrm{W}$ strategii marki od początku jej istnienia zrezygnowano $\mathrm{z}$ reklamy $\mathrm{w}$ tradycyjnych mass mediach na rzecz mediów społecznościowych. Głównym założeniem było wysyłanie zegarków do influencerów, którzy na swoich profilach osiagnęli liczbę followersów na poziomie minimum 10000 osób. Przedsiębiorstwo zwróciło się także do influencerów o dodanie odpowiedniego hashtagu i tagu przy opublikowanym poście $\mathrm{z}$ produktem.

Znajomość marki Daniel Wellington potwierdziło około 59\% respondentów i dla $95 \%$ z nich źródłem informacji był Internet. Jedynie $26 \%$ respondentów kiedykolwiek korzystało z produktów oferowanych przez markę Daniel Wellington.

W promocji marki Daniel Wellington korzystano z osób mniej znanych zakładając że będzie to przekaz bardziej wiarygodny, $\mathrm{i}$ tak np. sponsorowany post influencerki

${ }^{18} \mathrm{https}: / /$ www.hosandme.pl/listamarek/danielwellington (14.08.2018) 
(a) latajacaszafa to zdjęcie zegarka w naturalnym i estetycznym otoczeniu. Influencerka zgromadziła na swoim profilu ponad 13 tysięcy followersów, co przy obecnym dostępie do mediów społecznościowych jest wynikiem na poziomie średnim.

$\mathrm{Na}$ współpracy $\mathrm{z}$ influencerami marka korzysta w dwojaki sposób. Pierwszy to dotarcie do swoich potencjalnych odbiorców poprzez wykorzystanie kanałów influencerów. Druga korzyść to możliwość wykorzystania stworzonego contentu, do budowania własnych profili na platformach społecznościowych. W sierpniu 2018 roku marka na swoim oficjalnym profilu na Instagramie zgromadziła ponad 4,2 miliona followersów wykorzystując wyłącznie zdjęcia influencerów.

Inluencerzy wpływają również na zwiększenie sprzedaży produktów oferowanych przez markę. Na ich profilach regularnie pojawiają się posty, w których influencerzy informują swoich followersów o kodach rabatowych na zakup zegarków Daniel Wellington. Na publikowanych zdjęciach influencerzy informują o promocji na cały asortyment, lub na darmowy pasek do zegarka. Tego typu promocje zazwyczaj połączone są z konkretną datą jak np. Walentynki, Święta Bożego Narodzenia lub Mikołajki, chociaż bywa i tak, że kody są rozdawane bez konkretnej okazji.

Początkowo marka sama zapraszała influencerów do współpracy, a obecnie twórca sam może zgłosić się do marki, wysyłając maila na podany na stronie producenta adres. Przedsiębiorstwo prosi o podanie kraju pochodzenia influencera, imienia i nazwiska, numeru telefonu, adresu mailowego oraz linku do profili na portalach społecznościowych. Każdy wniosek jest rozpatrywany przez pracownika odpowiedzialnego za nowe kontakty z influencerami. Przykład Daniela Wellingtona pokazuje jak można zbudować wizerunek marki wykorzystując do tego wyłącznie influencerów. Dodatkowym argumentem potwierdzającym stosowność korzystania z twórców internetowych jest fakt, że marka w 2015r. uzyskała przychód na poziomie 220 milionów dolarów ${ }^{19}$.

\section{Marka NA-KD}

Marka NA-KD, zajmująca się internetową sprzedażą odzieży została założona przez Szweda, Jarno Vanhatapio w 2015 roku. Jest to jedna z 20 najszybciej rozwijających się firm $\mathrm{w}$ Europie. ${ }^{20}$ Jak wynika $\mathrm{z}$ dostępnych publikacji, głównym czynnikiem szybkiego rozwoju firmy było wykorzystanie influencer marketingu, jako głównego elementu strategii reklamowej przedsiębiorstwa. Marka ta wykorzystuje wielu mikroinfluencerów do promocji swoich produktów. W przeszłości marka współpracowała z influencerką, która na swoim koncie instagramowym posiadała ponad 1,6 miliona followersów. Po zakończeniu kampanii przeanalizowano wyniki sprzedaży dochodząc do wniosku, iż rezultaty były poniżej oczekiwań. Stąd pojawił się pomysł współpracy z mniejszą influencerką, która posiadała 350 tysięcy widzów na swoim kanale. Influencerka ta wygenerowała dużą liczbę transakcji sprzedażowych w ciagu jednej doby. Obecnie przedsiębiorstwo przekazuje swoim influencerom kody zniżkowe, które mają na celu zachęcić ich followersów do zakupów na stronie internetowej NAKD. W lutym 2018 roku marka otworzyła polską stronę internetową własnego sklepu. Jak można było się spodziewać, strategia marki będzie identyczna do tej realizowanej

\footnotetext{
${ }^{19} \mathrm{https} / / / \mathrm{www}$. danielwellington.com (12.08.2018)

${ }^{20} \mathrm{https}: / /$ www.na-kd.com/en/about (14.08.2018)
} 
od momentu jej powstania. Marka zaangażowała 3 ambasadorki: Kasię Tusk, Maffashion oraz Macademian Girl.

Zarówno ambasadorki, jak i mikroinfluencerzy publikują zdjęcia w stylizacjach marki NA-KD oraz dzielą się kodem rabatowym. Każdy post, oprócz ubrań od NA-KD oraz kodu w opisie, oznaczony jest również hashtagiem \#nakdfashion bądź czasami \#nakdxpolska. O popularności tej marki na Instagramie może świadczyć fakt, iż pod pierwszym hashtagiem w sierpniu 2018 roku można było znaleźć ponad 145 tysięcy zdjęć $^{21}$, a pod drugim ponad 3,5 tysiąca ${ }^{22}$.

Jak wynika z przeprowadzonego badania tylko $34 \%$ ankietowanych potwierdziło znajomość marki NA-KD, a 28\% przynajmniej raz skorzystało z oferty produktowej marki. Wynikać to może $\mathrm{z}$ faktu, iż marka na polskim rynku jest relatywnie nowa, a informacje o niej nie dotarły jeszcze do wielu osób. Dla 95\% ankietowanych znających markę głównym źródłem informacji był Internet.

Podobnie jak w przypadku marki Daniel Wellington, NA-KD również zachęca użytkowników do programu partnerskiego, za pomocą którego influencerzy mają możliwość otrzymywania wynagrodzenia za publikowanie zdjęć $\mathrm{z}$ artykułami dostępnymi na stronie NA-KD oraz dzielenia się unikalnym kodem rabatowym.

W kwestionariuszu ankiety zapytano respondentów o wpływ influencerów na podejmowanie decyzji zakupowych $\mathrm{i}$ zestawiono ten czynnik $\mathrm{z}$ innymi determinantami, co przedstawiono w tabeli 1.

Tabela 1. Determinanty zakupu produktów marki Daniel Wellington i NA-KD wśród klientów marki [\%]

\begin{tabular}{|l|c|c|}
\hline Determinanta & Daniel Wellington & NA-KD \\
\hline Marka & 30,9 & 30,1 \\
Cena & 11,9 & 9.8 \\
Jakość & 31,1 & 21,2 \\
Opinia w Internecie & 18,9 & 49,1 \\
Ambasador marki & 31,2 & 10,9 \\
Opinia znajomych & 11,9 & 89,1 \\
Polecenie influencera & 63,2 & \\
\hline
\end{tabular}

*Badany mógł wskazać więcej niż 1 odpowiedź

Źródło: wyniki badań własnych.

Za najważniejszy czynnik przy wyborze marki Daniel Wellington i NA-KD respondenci uznali polecenie influencera (odpowiednio 63\% i 89\% wskazań). Na drugim miejscu wskazali ambasadora marki (31\% i 49\%). W przypadku marki Daniel Wellington niemal co trzeci badany wymienił także markę i jakość produktu. Dla klientów sklepu internetowego NA-KD ważna też była cena (31\%). Za najmniej istotne uznano opinie znajomych, które były mniej ważne niż opinie w Internecie.

\section{Podsumowanie}

Influencerzy charakteryzują się dużym potencjałem, który w coraz większym stopniu wykorzystywany jest przez przedsiębiorstwa. Współcześnie coraz więcej osób

\footnotetext{
${ }^{21} \mathrm{https}: / /$ www.instagram.com/explore/tags/nakdfashion/ (15.08.2018)

${ }^{22} \mathrm{https} / / / \mathrm{www}$. instagram.com/explore/tags/nakdxpolska/ (15.08.2018)
} 
korzysta wyłącznie $\mathrm{z}$ Internetu rezygnując $\mathrm{z}$ tradycyjnych środków społecznego przekazu i aby dotrzeć do potencjalnych klientów przedsiębiorstwo powinno być obecne $\mathrm{w}$ sieci internetowej.

Jak wynika $\mathrm{z}$ przeprowadzonego badania ambasadorowie marek $\mathrm{z}$ zarazem influencerzy zwiększają rozpoznawalność marki i wpływają na jej wizerunek wśród konsumentów. $\mathrm{Z}$ kolei $\mathrm{w}$ procesie podejmowania decyzji zakupowych polecenie influencera ma większy wpływ na podejmowanie decyzji zakupowych niż ambasadorzy marek. Jednak dodatkowo należy pamiętać o szczegółowych uwarunkowaniach wynikających ze specyfiki branży i przedsiębiorstwa oraz potencjalnych interesariuszach. Dlatego tak istotny jest właściwy dobór influencerów. Przykładem mogą być marki Huawei i Żywiec Zdrój, których amabasadorzy, a zarazem influencerzy, niefortunnymi postami wpłynęli niekorzystnie na postrzeganie marki i co według deklaracji respondentów stało się ważnym czynnikiem przy podjęciu decyzji zakupowej ( np. $45 \%$ respondentów w przypadku marki Huawei). Skuteczne jest także korzystanie $\mathrm{z}$ potencjału istniejącego $\mathrm{w}$ twórcach posiadających małe zasięgi na platformach społecznościowych. Dobrym przykładem wykorzystania influencer marketingu są marki Daniel Wellington i NA-KD, a w szczególności druga $\mathrm{z}$ wymienionych, bowiem influencerzy mieli duży wpływ na budowanie pozycji marki i znalezienie się wśród najszybciej rozwijających się firm.

\section{Bibliografia}

Cook S.: Under the Influence: A New Perspective on Social Marketing, Wyd. skyword.com, London 2015.

https://consumer.huawei.com/pl/press/news/2018/kuba-wojewodzki-teamhuawei/ (13.08.2018) https://nowymarketing.pl/a/8830,8-nietypowych-taktyk-na-wypromowanie-tresci-w-social-media (12.04.2018)

https://sjp.pwn.pl/ciekawostki/haslo/influencer;6368873.html (18.05.2018)

https://www.danielwellington.com (12.08.2018)

https://www.instagram.com/explore/tags/nakdfashion/ (15.08.2018)

https://www.instagram.com/explore/tags/nakdxpolska/ (15.08.2018)

https://www.na-kd.com/en/about (14.08.2018)

https://www.na-kd.com/en/about (14.08.2018)

https://www.postronienatury.pl/co-w-tym-roku (13.08.2018)

https://www.wirtualnemedia.pl/artykul/talentmedia-i-lifetube-zintegruja-technologie-i-produkcjepozostana-osobnymi-markami (20.03.2019)

https://zarabiajnaturystyce.pl (10.03.2019)

Kaczorowska-Spychalska D.: Blogi w procesie komunikacji marketingowej, Wyd. Uniwersytetu Łódzkiego, Łódź 2016.

Kaznowski D.: Social media - społeczny wymiar Internetu. [w:] E-marketing. Współczesne trendy, Red. naukowa J. Królewski. P.Sala, Wyd. PWN, Warszawa 2013.

Kirkpatrick D.: Efekt Facebooka, Wyd. Wolters Kluwer, Warszawa 2011.

Stopczyńska K.: Wykorzystanie influencer marketingu $w$ kreowaniu relacji z klientami pokolenia Y, Studia Oeconomica Posnaniensia, 2018,vol.6, nr 5.

Stopczyński B.: Facebook $w$ komunikacji marketingowej - użyteczność dla firm rodzinnych, Przedsiębiorczość i Zarządzanie, T.XV, Zeszyt 7, Część III/ 2014.

The rise of influencer marketing. https://influencermarketinghub.com/the-rise-of-influencermarketing $(2.03 .2019)$ 
Wicińska K.: Media społecznościowe jako narzędzie rozwijajace działania marketingowe przedsiębiorstw, Czasopismo Rynek - Społeczeństwo - Kultura, Nr 3(24) 2017.

Wilusz R.: Influencer Marketing potężny ponad miarę, Marketing (r)Evolution. Nowe techniki, pomysły, rozwiązania, Oficyna Wydawnicza Politechniki Rzeszowskiej, Rzeszów 2017.

\section{Summary}

The study aims to explore the phenomenon of influencer marketing and determine the influence of ambassadors and influencers on brand recognisability and creating a brand image. The paper defines the term influencer and investigates the use of Facebook and Instagram to propel a brand. The study uses the examples of 4 brands (Żywiec Zdrój, Huawei, Daniel Wellington and NA-KD) to describe the contribution of ambassadors and influencers to the brand image and product promotion. The study involved a questionnaire carried out to verify the research assumption regarding the impact of influencers on brand recognition and image, as well as consumers' purchasing decisions.

The brands Daniel Wellington and NA-KD were helpful in illustrating the potential existing in influencers with limited number of followers on social platforms while brands like Żywiec Zdrój and Huawei cooperated with widely recognized influencers who are also their ambassadors (Martyna Wojciechowska and Kuba Wojewódzki). The conducted research showed that brand ambassadors and influencers increase brand recognition and influence its image as perceived by consumers. The influencer's recommendation has a greater impact on purchasing decisions than brand ambassadors. The study involved the review of literature and source materials, the case study method and the diagnostic survey.

Key words: influencer marketing, brand, influencer, image, brand ambassador

Informacja o autorach

Dr inż. Ewa Jaska

Szkoła Główna Gospodarstwa Wiejskiego w Warszawie

Wydział Nauk Ekonomicznych

Katedra Ekonomiki Edukacji, Komunikowania i Doradztwa

e-mail:ewa_jaska@sggw.pl

ORCID:0000-0002-3874-1985

Dr inż. Agnieszka Werenowska

Szkoła Główna Gospodarstwa Wiejskiego w Warszawie

Wydział Nauk Ekonomicznych

Katedra Ekonomiki Edukacji, Komunikowania i Doradztwa

e-mail:agnieszka_werenowska@sggw.pl

ORCID:0000-0002-2545-4442 